\title{
Julgamentos penais em períodos de transição e o desafio das emoções: Histórias de dois países
}

Transitional Criminal Trials and the Emotional Challenge: Tales from Two

Countries

Jugements pénaux en périodes de transition et le défi des émotions : histoire de

deux pays

Mihaela Mihai

Tradutor. Inês Martins Ferreira

\section{(2) OpenEdition}

\section{Journals}

Edição electrónica

URL: http://journals.openedition.org/rccs/1728

DOI: $10.4000 /$ rccs. 1728

ISSN: 2182-7435

Editora

Centro de Estudos Sociais da Universidade de Coimbra

Edição impressa

Data de publição: 1 Março 2010

Paginação: 155-184

ISSN: 0254-1106

\section{Refêrencia eletrónica}

Mihaela Mihai, « Julgamentos penais em períodos de transição e o desafio das emoções: Histórias de dois países », Revista Crítica de Ciências Sociais [Online], 88 | 2010, colocado online no dia 01 outubro 2012, criado a 19 abril 2019. URL : http://journals.openedition.org/rccs/1728 ; DOI : 10.4000/ rccs. 1728 


\section{Julgamentos penais em períodos de transição e o desafio das emoções: Histórias de dois países}

$\mathrm{O}$ artigo visa analisar o modo como dois tribunais nacionais proferiram sentenças penais em circunstâncias de mobilização emocional e tensão política. As decisões a que se chegou na Argentina depois de 1983 e na Roménia, após o fim da ditadura de Ceaus, escu, ilustram a forma como os afectos dos cidadãos influenciam as deliberações dos tribunais no âmbito de processos penais. Ambos os casos demonstram como o poder judicial teve de entrar em diálogo com pedidos de reparação ressentidos e indignados. No entanto, enquanto o tribunal argentino filtrou as emoções garantindo um respeito igual por ambas as partes, impulsionando, assim, a causa da justiça democrática, o caso romeno serve de advertência sobre a maneira como não se deve usar o direito penal para corrigir erros cometidos. Estes dois casos oferecem-nos duas importantes lições acerca tanto dos obstáculos como das oportunidades associados às emoções públicas durante períodos de transformação política radical.

Palavras-chave: Argentina; emoções manifestas; julgamentos; justiça de transição; poder judicial; processo penal; reparação de danos; Roménia; vitimadores.

O presente artigo procura examinar uma das dimensões menos teorizadas da justiça de transição, os afectos públicos, e o papel que os julgamentos penais desempenham quando se lida com sentimentos negativos de ressentimento e indignação contra vitimadores, sejam eles reais ou imaginados. Devido à sua natureza dramática, os julgamentos em períodos de transição e as emoções que os rodeiam têm sido objecto de inúmeros estudos (Arendt, 1963; Nino, 1996; Osiel, 1997; Penrose, 1999; Bass, 2000; Douglas, 2000; Heyner, 2001; Bassiouni, 2002; Uitz, 2005; Bilsky, 2007). Embora tenha sido dada a devida atenção aos obstáculos que estas emoções colocam à garantia de imparcialidade das decisões, pouco tem sido dito acerca da capacidade de esses julgamentos envolverem, de forma construtiva, o afecto reactivo dos que a eles assistem. 
Defendo a tese de que os tribunais penais podem, também, contribuir para a formação de uma cultura sentimental democrática. Para que a democracia prospere enquanto ordem institucional, é necessário que ela esteja ancorada numa cultura pública propícia. As decisões judiciais em processos penais podem suscitar e socializar as emoções negativas características de sociedades em situação de pós-conflito, tornando-as compatíveis com a igualdade de respeito e preocupação com todos os membros da comunidade política. Os argumentos e estratégias adoptados por diferentes juízes podem variar, porém, têm de partilhar um objectivo comum: reconhecer a adequação do ressentimento e indignação contra os vitimadores e, simultaneamente, veiculá-los de um modo que não seja nocivo à integridade normativa e à estabilidade da democracia.

Parto da premissa de que o ressentimento e a indignação dos cidadãos para com os vitimadores funcionam como barómetros de injustiça e como sinais de alarme para que as instituições intervenham com medidas correctivas. O ressentimento corresponde a uma injustiça cometida contra o próprio e a indignação a uma injustiça cometida contra outrem. A designação "negativa" reporta-se à sua associação com descontentamento e mal-estar. Estas reacções podem estar relacionadas, primeiramente, com a vivência de actos moralmente condenáveis sob a forma de violação dos direitos humanos e, em segundo lugar, com a incapacidade de a comunidade política corresponder a pedidos legítimos de reparação e justiça. É importante observar que a mudança democrática é, na maioria das vezes, imaginada como uma (re)instauração da normalidade, no sentido da criação ou do regresso a condições de igualdade perante a lei e de previsibilidade governamental. As expectativas anteriores à transição, até então abafadas por medo ou falta de confiança social, manifestam-se e exigem reparação, como é natural. Caso fosse novamente negada a voz às vítimas, os danos e ofensas seriam redobrados, colocando em perigo a integridade do regime democrático normativo. ${ }^{1}$ Acresce ainda a possibilidade de o ressentimento e indignação degenerarem em desilusão e apatia política, pondo, assim, em causa o desempenho das funções de responsabilização por parte da sociedade civil. Também a estabilidade do regime político seria ameaçada, uma vez que os sentimentos negativos não assumidos podem reproduzir-se de geração para geração.

\footnotetext{
1 Walker refere-se à falta de reconhecimento do sentimento de cólera da vítima por parte da comunidade e das autoridades como sendo um "abandono normativo da vítima" (Walker, 2006). De um ponto de vista democrático, é moralmente errado não reparar violações passadas. Ignorar os pedidos de reparação significaria ofender as vítimas uma outra vez.
} 
Neste artigo, serão analisados dois julgamentos de âmbito nacional organizados no seguimento de situações de opressão e de atrocidades apadrinhadas pelo Estado. Embora não pretenda descartar o enorme potencial que os tribunais internacionais e os tribunais híbridos possam vir a ter no futuro, os défices de legitimidade, o enquadramento legal ainda incompleto que lhes é subjacente, os desequilíbrios na acusação de arguidos africanos no Tribunal Penal Internacional, ${ }^{2}$ bem como a distância existente entre esses tribunais e as sociedades no seio das quais ocorreram actos de violência, fazem com que, até à data, a sua utilização tenha sido problemática. ${ }^{3}$ Com vista a assegurar o domínio local da justiça, o reforço do sistema jurídico e os efeitos benéficos de socialização desses julgamentos, deve ser dada prioridade às instituições nacionais. A confiança civil depositada no poder judicial não será (re)construída, se não for dada aos tribunais a oportunidade de prestarem o seu contributo para a democratização. São estas as razões pelas quais os tribunais nacionais devem ter preferência, desde que sejam funcionais. Como veremos mais adiante neste artigo, existem boas razões para optar pelos julgamentos nacionais. Espera-se que as lições retiradas do estudo destes casos possam ser úteis para melhorar o modo como as organizações internacionais podem contribuir para os esforços da justiça de transição no seio de sociedades que estejam a libertar-se da violência e opressão, sem se apropriarem deles à força.

Os casos a ser apresentados neste artigo representam dois extremos. Por um lado, surge a decisão edificante da justiça argentina que procurou contribuir para a luta pela memória e igualdade de cidadania. Num clima de efervescência emocional, os juízes argentinos fizeram o possível por demonstrar igual preocupação, tanto pelas vítimas, como pelos vitimadores, reforçando, assim, o seu compromisso com os valores democráticos. Por outro lado, temos os procedimentos ilegítimos, instigados pelo ódio, na Roménia, que fracassaram na afirmação de princípios democráticos. Pressionados por cidadãos mobilizados pelas emoções, os juízes romenos usaram os antigos líderes comunistas como bodes expiatórios. Foram, assim,

\footnotetext{
${ }^{2}$ Para obter uma lista dos julgamentos pendentes, consultar a página web do tribunal: http://www. icc-cpi.int/Menus/ICC/Situations+and+Cases/Cases/.

3 Sobre uma série de artigos dedicados às deficiências detectadas em julgamentos internacionais, ver Stover e Weinstein (2004). Ver também Rabkin (2005); Mégret (2005); Henham (2007). Embora não pretenda descartar a contribuição que os tribunais não-estatais podem dar aos processos de justiça de transição, sobretudo quando os tribunais nacionais são corruptos ou se encontram subordinados ao poder político, as falhas existentes nos tribunais internacionais ou nos tribunais híbridos deverão alertar-nos para não nos precipitarmos a aplaudir o seu trabalho. São necessárias reformas antes de estes tribunais poderem alcançar os padrões de legitimidade e eficiência que prometem.
} 
incapazes de marcar a descontinuidade com um passado de opressão e de se envolverem, de forma construtiva, com uma indignação que não deixava de ser legítima.

Deve ser dada especial atenção às variáveis contextuais que fornecem o enquadramento para o juízo ponderado dos tribunais. O primeiro estudo de caso foi seleccionado com vista a ilustrar uma estratégia apropriada, em termos democráticos, ao reconhecimento da validade das emoções negativas e à condenação de todas as formas de impunidade. O segundo caso ilustra o lado negativo, ou seja, mostra aquilo que o poder judicial deveria, tanto quanto possível, evitar fazer no rescaldo de um regime repressivo. O julgamento de fachada do casal Ceaușescu, em Dezembro de 1989, é exemplo de um ódio moral sem peias por parte do próprio poder judicial, agravado por um contexto de manipulação e incerteza política. O artigo termina com um conjunto de conclusões acerca dos obstáculos práticos, mas também das oportunidades que se encontram associadas a processos penais de âmbito nacional no seio de sociedades emocionalmente mobilizadas.

Uma advertência antes de mergulhar numa análise comparativa: dado que os tribunais não são as únicas instituições a tentar resolver situações que envolvem populações afrontadas no decurso de transformações políticas, seria difícil quantificar o impacto que as suas decisões tiveram nas emoções. Esse impacto dependerá da capacidade de os tribunais proferirem decisões de uma forma que faça passar a mensagem dos limites impostos pelo respeito por ambas as partes quanto à manifestação de emoções, à colaboração de outras instituições, à transparência, publicidade e exposição nos media, assim como quanto à receptividade das vítimas, só por si uma função de muitas variáveis. $\mathrm{Na}$ medida em que este artigo reivindica que alguns tribunais tiveram "êxito", entenda-se por "êxito" a qualidade da mensagem democrática comunicada às vítimas, aos vitimadores e à sociedade em geral, e não propriamente a eficácia que terão tido na mudança de emoções das pessoas. Não se pretende, com isto, estabelecer qualquer nexo causal entre as decisões oficiais dos tribunais e as respostas da sociedade civil. Isso seria matéria para um outro artigo.

\section{Argentina}

A única luta que se perde é aquela que se abandona.

Mães da Praça de Maio

O fim do regime militar argentino só teve lugar com a derrota na Guerra das Falkland, no início da década de oitenta. Durante o regime militar, o Supremo Tribunal do país tinha dirigido sucessivas petições aos governantes 
para que estes esclarecessem a situação jurídica dos indivíduos desaparecidos, mas foi sistematicamente ignorado por uma junta militar que alegava não ter qualquer conhecimento do que estava a passar-se (Jacobson, 2007). Imediatamente antes de perderem o poder, os militares aprovaram uma lei de auto-amnistia, a Lei de Reconciliação Nacional 22924, que estipulava uma amnistia geral para todos os actos subversivos e contra-subversivos que tivessem ocorrido entre 25 de Maio de 1973 e 17 de Junho de 1982. Deste modo, os oficiais deixaram o poder com a garantia de que as violações dos direitos humanos - sendo os mais infames os "desaparecimentos" de um grande número de cidadãos argentinos suspeitos de actividades esquerdistas contra o regime - não seriam passíveis de acusação em tribunal.

Imediatamente após tomar o poder, o presidente Raúl Alfonsín veio contestar a constitucionalidade da Lei de Reconciliação Nacional, que viria a ser anulada. Em consequência, foi iniciada uma acção contra as altas patentes militares e os guerrilheiros de esquerda que tivessem cometido violações em massa dos direitos humanos.

A fim de apaziguar o poder militar, a tarefa de conduzir a acção judicial foi confiada ao supremo tribunal militar. No entanto, quando este se recusou a conduzir julgamentos, os processos foram transferidos para tribunais civis (Nino, 1996). Para além disso, o presidente pediu que a defesa baseada na "obediência devida" fosse considerada válida. Tal significava que os militares de patente inferior poderiam utilizar em sua defesa a justificação de terem apenas obedecido a ordens dos seus superiores. Devido à fragilidade do equilíbrio de poder depois de 1983, Alfonsín e a sua equipa de juristas optaram pela prudência e contenção na demanda pela justiça. A sua intenção era realizar um julgamento exemplar dos altos dirigentes do exército, de modo a satisfazer as exigências de justiça por parte da sociedade, sem que as medidas da justiça de transição parecessem um ataque dirigido contra a instituição militar.

O julgamento dos dirigentes das juntas militares em 1985 foi recebido com grande efervescência pública (Nino, 1996). Os generais Videla e Massera foram condenados a prisão perpétua, Agosti a quatro anos e meio, Viola a dezassete anos e Lambruschini a oito anos. Graffigna e os restantes três membros da terceira junta foram absolvidos (Di Paolantonio, 2004). ${ }^{4}$ O defeito do julgamento foi a posição pouco clara no tocante à "obediência devida”. Esta ambiguidade viria a abrir caminho para outras acções judiciais.

\footnotetext{
${ }^{4}$ Videla, Massera e Agosti eram membros da primeira junta militar que tomou o poder após a presidente Isabel Perón ter sido deposta em 1976. O general Viola substituiu Videla por alguns meses em 1981 como presidente da junta. O almirante Lambruschini ocupou o cargo de Massera como chefe da marinha. Graffigna sucedeu a Agosti, como comandante da força aérea.
} 
Como seria de esperar, o poder militar cerrou fileiras e começou a ameaçar romper com uma paz que era, só por si, já frágil (Di Paolantonio, 2004). Em resposta a esta situação, o presidente e os seus assessores prepararam, com a devida prudência, duas leis destinadas a limitar o impacto das acções judiciais. A primeira, a chamada Lei do Ponto Final (23492 Punto Final, 1986), dava aos tribunais e aos promotores de justiça um prazo de 60 dias para intentar acções judiciais. Inesperadamente, os tribunais revelaram-se muito diligentes e intentaram numerosos processos antes de esse prazo expirar, tendo até mesmo trabalhado durante o período de férias. Em consequência, o poder militar organizou uma séria rebelião, que pressionou a aprovação da "Lei de Obediência Devida" (23521 Obediencia Debida, 1987), limitando a responsabilidade apenas às patentes mais elevadas. Esta segunda lei travou todas as acções judiciais intentadas contra oficiais de patentes intermédias. O Supremo Tribunal confirmou a constitucionalidade da lei, que era contestada por grupos defensores dos direitos humanos. $\mathrm{E}$ assim se interrompeu a marcha da justiça. O golpe final para as vítimas e respectivas famílias viria, pouco tempo depois, a assumir a forma do perdão concedido pelo presidente Menem a todos os oficiais que já tivessem sido condenados por crimes cometidos durante a "guerra suja". Somente em 2005, após uma longa luta contra a impunidade e uma persistente mobilização social e jurídica, é que estas leis e o vergonhoso acto de perdão foram, finalmente, declarados inconstitucionais.

Em seguida, passarei a analisar o julgamento dos membros das três primeiras juntas militares em 1985, para assim ilustrar uma abordagem exemplar do problema de manter a integridade da preocupação com todas as partes e do envolvimento construtivo com as emoções negativas do público. Este primeiro julgamento após o final do regime militar é de extremo interesse para os propósitos deste artigo. O complicado contexto sociopolítico em que teve lugar e o veredicto a que o tribunal chegou fazem deste julgamento um caso exemplar quanto ao que pode ser feito, mesmo em condições de extrema tensão.

Por um lado, o período que antecedeu o julgamento tinha sido marcado por uma intensa mobilização emocional por parte da sociedade. A lei da auto-amnistia aprovada pelo último governo militar - posteriormente declarada inconstitucional - provocou uma vaga de indignação que fez o povo sair às ruas. Também foram organizadas manifestações de grande dimensão no dia em que teve início, em Buenos Aires, o julgamento das três primeiras juntas militares. Segundo Carlos Santiago Niño, um dos mais salientes consultores jurídicos do presidente Alfonsín, cinquenta mil pessoas marcharam nas ruas da capital para apoiar o julgamento (Nino, 1996: 82). Extremamente 
activas antes da mudança de regime, as associações de vítimas e familiares de vítimas fizeram pressão junto das jovens instituições democráticas, para que estas assumissem uma posição quanto ao passado escandaloso do país. De entre as muitas organizações da sociedade civil que tomaram parte neste esforço, o Centro de Estudos Jurídicos e Sociais e as Mães da Praça de Maio foram as duas principais forças políticas que se destacaram na luta pela responsabilização jurídica. Emblemático é também o facto de a CONADEP - a Comissão de Verdade argentina, criada, em 1983, pelo presidente Alfonsín com o intuito de recolher informações sobre os desaparecidos ${ }^{5}-$ ter contado com uma vasta participação voluntária e inúmeros testemunhos, quer das vítimas, quer das famílias dos desaparecidos. O relatório final da Comissão documentava os cerca de nove mil desaparecidos e a existência de 365 centros de detenção secretos. As conclusões do relatório acerca das práticas repressivas dos militares serviram de prova no julgamento da primeira junta.

Por outro lado, a ameaça de rebelião militar era grande depois da transferência do poder a favor para o governo civil presidido por Alfonsín. A Argentina estava bem familiarizada com golpes militares. As constantes ameaças do exército vieram dificultar imenso as tarefas do governo e, por fim, fizeram com que as acções judiciais contra os oficiais arguidos ficassem paradas até 2005. A nova elite política viu-se, portanto, apanhada no meio de duas poderosas forças: as exigências da sociedade, imbuídas de carga emocional, no sentido de reafirmar a igualdade, e o risco de um novo golpe militar.

Tendo em conta a crescente mobilização social contra os represores, o presidente, após assumir o poder em 1983, decretou que os membros das três primeiras juntas militares, bem como alguns dirigentes notórios das forças esquerdistas a quem estes faziam frente, fossem levados a julgamento. A Argentina tinha sido marcada por uma situação de "barbarismo simétrico", ${ }^{6}$ com atrocidades a serem cometidas por ambas as partes do conflito civil, a guerrilha esquerdista a envolver-se em actos de terrorismo antes do golpe militar, e as forças armadas a retaliar com raptos e execuções extrajudiciais dos suspeitos de subversão. O presidente recém-eleito queria adoptar uma abordagem imparcial das atrocidades e evitar demonizar uma das partes e tornar a outra em mártir. A sua preocupação com a verdade histórica e a justiça levaram-no a condenar, quer a repressão exercida pelo Estado,

\footnotetext{
5 As formas mais comuns de repressão eram o rapto de pessoas suspeitas de subversão, o internamento e a tortura, com o propósito de obter informações, seguidos, na maior parte das vezes, pelo assassínio. Ver Americas Watch (1991:13-14).

${ }^{6}$ A expressão é de Rajeev Bhargava (2000).
} 
quer a violência política anti-sistema. Será desnecessário dizer que havia, ainda, a esperança de apaziguar o poder militar com este esforço de também levar a julgamento os subversivos de esquerda, e não apenas elementos das suas próprias fileiras.

O Código Militar Argentino previa que os membros das forças armadas fossem julgados por tribunais militares, independentemente de os seus crimes constituírem uma violação da lei militar ou penal, ou de terem sido cometidos em serviço em local sob jurisdição militar. Por respeito por esta lei, e de modo a facultar ao poder militar a possibilidade de policiar os seus próprios membros, o presidente decretou que os oficiais responsáveis pela governação do país entre 1976 e 1982 deveriam ser levados a julgamento perante o mais alto tribunal militar, o Conselho Supremo das Forças Armadas (Amnesty International, 1987: 10-13). Porém, com vista a assegurar o fim da impunidade estrutural, foi aprovada uma lei (23049/1984) que possibilitava recorrer das decisões tomadas por este alto tribunal militar junto dos tribunais nacionais. ${ }^{7}$ Para além disso, caso as acções judiciais não ficassem concluídas num prazo de seis meses após a primeira sessão, o Conselho Supremo teria de fornecer ao Tribunal Federal de Apelação competente um relatório a explicar a situação. Caso se verificassem atrasos sem justificação e negligência por parte do tribunal militar, o tribunal civil tomaria conta do processo, independentemente da fase em que este se encontrasse. Ao aprovar esta legislação, foi violado o princípio da não retroactividade, com o propósito de garantir que o julgamento não seria um acto de justiça meramente simbólico. Tendo em consideração o número estimado de vítimas - entre dez mil e trinta mil (Kritz, 1995: 323) - o governo não quis deixar que o poder militar cerrasse fileiras, insultando a memória dos desaparecidos e o sofrimento dos seus familiares.

Chegado o Outono de 1984, o Conselho Supremo não só não tinha concluído os processos como também se declarou incapaz e indisponível para prosseguir com o julgamento contra os membros da junta militar. No seu relatório, os membros do Conselho consideravam que as estratégias dos oficiais participantes na luta contra a esquerda eram irrepreensíveis e concluíam que os elementos subversivos não tinham qualquer direito a beneficiar de protecção jurídica. Além disto, o Conselho argumentava que os testemunhos das vítimas não eram apenas indignos de confiança, mas também parte de uma conspiração antimilitar.

Confrontado com mais um exemplo de impunidade estratégica, o público ficou horrorizado. A sua indignação ficou bem representada na imprensa

\footnotetext{
7 Para mais pormenores, ver Ley 23049, 1984.
} 
da época (Mignone et al., 1985). Perante a situação, o Tribunal Federal de Apelação de Buenos Aires tomou conta dos processos e o julgamento teve início a 25 de Abril de 1985. Os arguidos, os oficiais Videla, Massera, Agosti, Viola, Lambruschini, Graffigna, Anaya, e Lami Dozo responderam por 711 acusações de homicídio, detenção ilegal, tortura, roubo e violação. Embora a sua culpabilidade não se limitasse a estas acusações, a quantidade de provas fidedignas, assim como as considerações pragmáticas relacionadas com a constante ameaça de rebelião militar, e os constrangimentos de tempo levaram o promotor Strassera a limitar as acusações a estes casos. O tribunal veio reforçar o ponto de vista da acusação, apresentando uma outra razão normativa para limitar as acusações a 711: o direito dos arguidos a um julgamento rápido.

A Argentina, à semelhança de muitos países latino-americanos, tem uma forte tradição de direito civil. Os processos penais inseridos em sistemas de direito civil assumem predominantemente a forma escrita; contudo, devido à importância histórica deste julgamento, à necessidade de transparência e, acrescentaria eu, devido à importância de dar resposta ao ressentimento das vítimas e das suas famílias, assim como à indignação de grupos mobilizados no seio da sociedade civil, o Tribunal permitiu um contra-interrogatório oral dos arguidos. A imprensa tinha lugares reservados e cerca de 100 cidadãos puderam assistir ao julgamento, com base num sistema de convites. Deste modo, ficou preenchido o requisito de publicidade. No entanto, posteriormente, quando o público presente irrompeu em manifestações marcadas por emoções negativas, os juízes ordenaram a evacuação da sala, num esforço de garantir que se mostrasse igual respeito pelas vítimas e pelos vitimadores (Amnesty International, 1987).

Esta não foi a única forma através da qual os juízes do Tribunal Federal de Apelação procuraram assegurar a integridade normativa da democracia recém-estabelecida, e prestar igual atenção a ambos os lados do conflito. Durante o julgamento, foram chamadas a depor aproximadamente 800 testemunhas, a maioria das quais arroladas pela acusação. Muitas delas eram vítimas, que foram ouvidas de forma adequada, apesar de a defesa tentar, incessantemente, desacreditar os seus testemunhos (Amnesty International, 1987). As descobertas da CONADEP desempenharam um importante papel, ao demonstrar que os testemunhos prestados perante a comissão e o tribunal não se contradiziam e provar, assim, a implausibilidade da acusação de conspiração antimilitar. Deste modo, a divisão dos esforços entre mecanismos de justiça e de apuramento da verdade teve êxito no preenchimento das várias necessidades da transição imediata. 
O veredicto do tribunal continha duas mil páginas que apresentavam detalhadamente cada um dos 700 casos que acabaram por ser apreciados pelo tribunal (Amnesty International, 1987). Os juízes descreveram, sem pressas, as linhas gerais do plano criminoso da junta. As forças armadas

[...] detiveram um grande número de pessoas, alojaram-nas clandestinamente em unidades militares ou em locais controlados pelas forças armadas, submeteram-nas a interrogatórios sob tortura, mantiveram-nas em cativeiro em condições desumanas, e, por fim, levaram essas pessoas a tribunal ou perante o poder executivo nacional, libertaram-nas ou assassinaram-nas. Estes actos, que implicam uma derrogação secreta das leis em vigor, foram executados em concordância com planos aprovados e postos em prática pelos comandantes militares. (Argentina, 1987: 333)

Seguia-se uma condenação dos meios usados pela junta para combater a subversão, do seu secretismo e da sua impunidade estratégica:

Os arguidos não hesitaram em menosprezar a lei, de forma a obter poder político, através do uso da tortura, de um tratamento desumano, do trabalho forçado e da imposição da crença de que ninguém poderia ajudar os cativos. [...] Com base nas provas [...] pode concluir-se que os arguidos sonegaram deliberadamente os factos ao conhecimento dos tribunais, das famílias das vítimas, de instituições e organizações estrangeiras, da Igreja, dos governos de países estrangeiros, e da sociedade em geral. (Argentina, 1987: 333)

Revelar os abusos cometidos no passado e dar-lhes voz institucional foi extremamente importante no período subsequente às atrocidades em massa cometidas sob um espesso véu de secretismo. Os testemunhos dos sobreviventes foram especialmente importantes, dada a natureza da repressão política deste caso: rapto, prisão e tortura em centros de detenção clandestinos, execuções à queima-roupa e o arremesso de prisioneiros sob o efeito de narcóticos de aviões que sobrevoavam o Atlântico. ${ }^{8}$

Não obstante, existiu um equilíbrio entre a atenção dada à necessidade de reconhecimento por parte das vítimas e a preocupação com os direitos processuais dos arguidos. O volume de provas produzidas pela CONADEP e no âmbito do processo era mais do que suficiente para condenar os oficiais; ainda assim, o tribunal teve o cuidado de travar um diálogo minucioso com

\footnotetext{
${ }^{8}$ Em 2005, o tristemente célebre oficial Scilingo foi finalmente condenado a trinta anos de prisão, por ter arremessado ao mar trinta militantes de esquerda, durante dois voos sobre o Atlântico. Ver Tremlett (2005).
} 
a defesa. A preocupação dos juízes com a legitimidade dos procedimentos tomou a forma de um extenso veredicto, no qual foram meticulosamente contempladas todas as contestações da defesa. Além disso, a decisão continha extensas secções dedicadas a justificar a escolha da lei, os princípios a ela subjacentes, e a teoria da culpabilidade subscrita pelo tribunal. Os métodos e critérios de avaliação das provas, as diferentes justificações apresentadas pelos arguidos, e as opiniões dos juristas foram, todas elas, devidamente consideradas no texto da decisão. Desta forma, o tribunal demonstrou a importância dos interesses e da igualdade do estatuto jurídico dos arguidos. O desejo de se demarcar das arbitrariedades e ilegalidades do regime militar levou o tribunal a escolher um caminho mais longo para chegar à sentença. Ao delinear os contornos de ambos os lados da história, ao dar voz quer a vítimas, quer a vitimadores, o tribunal convidou o público em geral a reflectir sobre as narrativas concorrentes que estavam a ser apresentadas e a tomar decisões informadas sobre o significado do passado.

A preocupação com desfazer quaisquer acusações de procura de bodes expiatórios e de revanchismo político evidenciou-se com toda a clareza no modo sério e caritativo como os juízes se confrontaram com as quatro justificações apresentadas pela defesa para explicar a maneira como os acusados tinham conduzido a "guerra suja". Um a um, os argumentos das equipas de advogados dos oficiais foram confrontados de forma crítica e dialógica.

A primeira justificação dada pelas juntas foi o argumento do "estado de necessidade". Elas argumentavam que as forças armadas tinham tido de recorrer a meios extraordinários para impedir que os subversivos aterrorizassem a população e comprometessem os valores fundamentais da sociedade argentina. $\mathrm{O}$ tribunal concordou com os arguidos que a Argentina estava a sofrer um aumento do terrorismo esquerdista durante a década de 70 :

[...] ficou provado que a subversão terrorista se tornou uma condição sem a qual os actos criminosos sob avaliação não teriam, provavelmente, ocorrido. Além disso, o tribunal reconhece que esses actos terroristas representaram um acto ilegal de agressão contra a sociedade e o Estado argentinos. É também reconhecido por este tribunal que a sociedade argentina se viu obrigada a agir. Esta reacção era necessária para prevenir o aumento do terrorismo, que colocaria em perigo a estabilidade das instituições, cujos fundamentos filosóficos estão consignados na Constituição Federal. (Argentina, 1987: 347)

A defesa com base no argumento do "estado de necessidade" encontrava-se estipulada no Código Penal argentino como uma situação em que a consumação de um crime se torna necessária para evitar um mal maior iminente, 
e pela qual o autor material não é responsável. Esse mal que o poder militar tentava prevenir eram homicídios, roubos e actos bombistas praticados pelos subversivos, assim como a destruição do próprio Estado argentino. Porém, esta defesa não podia ter sustentação, uma vez que

[S]e a ideia era matar e sequestrar, de modo a impedir que os grupos subversivos continuassem a matar e sequestrar, então esta não seria uma situação em que se recorreria a um mal "menor" para evitar um mal "maior". Ambos os males teriam resultado, na melhor das hipóteses, em igual dano. Portanto, a defesa por necessidade não é aceitável. (Argentina, 1987: 349)

Além do mais, o perigo de o governo ser tomado pelas guerrilhas não estava, de modo algum, iminente. Os subversivos não tinham assumido o controlo de nenhuma parte do território; não eram apoiados por nenhuma potência estrangeira e não contavam com o apoio da população. Todas estas variáveis contribuíram para demonstrar que o argumento do "estado de necessidade" não tinha qualquer consistência. Os juízes prosseguiram, enumerando, de forma pedagógica, as medidas legais e administrativas que as juntas poderiam ter tomado, com vista a combater o fenómeno terrorista sem terem resvalado para as atrocidades e a arbitrariedade. Esta decisão é emblemática das intenções pedagógicas do tribunal, na medida em que revela formas através das quais mesmo os conflitos mais violentos podem ser resolvidos no seio de uma democracia.

A segunda defesa alegada pelos arguidos era a de que a sua estratégia para combater os subversivos estava em conformidade com a lei em vigor na época. Mais exactamente, recorriam aos Decretos n. ${ }^{\circ} 261$, de Fevereiro de 1965 , e n. ${ }^{\circ} 2770$, de Outubro de 1965 , que regulavam a existência legal de "um estado de guerra" (Argentina, 1987: 350). Com base nestes decretos, os oficiais defendiam que, estando em guerra, tinham de tomar todas as medidas necessárias contra o inimigo.

Em resposta, o tribunal começou por salientar que estes decretos tinham sido aprovados antes do golpe de 1976, quando o exército ainda se encontrava sob controlo civil e numa altura em que a Constituição ainda estava em vigor. Pressupunha-se, assim, que, ao emitir um decreto que ordenava às forças armadas que "eliminassem a capacidade dos elementos subversivos para agirem em toda e qualquer parte do território nacional," 9 o presidente não poderia ter em mente uma "eliminação física". Tal decreto teria sido inconstitucional e teria violado a ordem e a tradição jurídicas

\footnotetext{
${ }_{9}$ Decreto $\mathrm{n}^{\circ}$ 2772, citado em Argentina (1987: 350).
} 
da Argentina. Pelo contrário, os autores referiam-se expressamente à eliminação das capacidades de combate. Portanto, visto não existir lei alguma que autorizasse os crimes cometidos pelos militares, a defesa por obediência a um dever jurídico também não era válida.

A terceira defesa apresentada pelos arguidos consistia em afirmar que os seus métodos se justificavam com a defesa da sociedade e do Estado. Os juízes definiram autodefesa como "a reacção necessária contra uma agressão injusta, presente e não provocada" (Argentina, 1987: 351). De acordo com o Código Penal do país, a autodefesa orientava-se por uma necessidade de pôr fim a uma agressão ilegítima e não provocada. ${ }^{10}$ Embora os juízes concordassem que as forças subversivas não tinham sido provocadas e considerassem ilegítimos os meios por elas usados, também punham em causa se os meios usados pelas juntas em defesa do Estado e da sociedade argentinos teriam sido razoáveis. Mesmo se, em determinados casos, a detenção de pessoas armadas fosse justificada, a tortura, a privação ilegal de liberdade e o homicídio não eram admissíveis:

A maioria dos actos em causa foi cometida com o intuito, inerentemente plausível, de refrear o terrorismo. Os arguidos conceberam uma linha de acção de acordo com a qual era necessário recorrer a métodos inéditos, suficientemente eficazes para fazer frente a uma agressão também inédita. A alegação de que os novos métodos passavam no teste da razoabilidade dos meios empregues é inaceitável, quer do ponto de vista moral, quer do ponto de vista jurídico. Tendo em conta os meios repressivos que o Estado tem ao seu dispor para refrear o terrorismo, e após uma análise detalhada dos mesmos, estamos convencidos de que os requisitos do teste de razoabilidade não foram cumpridos. (Argentina, 1987: 352)

A quarta, e última, defesa foi a polémica alegação de que tudo é permitido num estado de guerra. A guerra não deixa "espaço para a lei, a moderação, a ética, a religião ou os princípios humanitários" (Argentina, 1987: 355). De modo a refutar a posição maquiavélica das juntas em relação à guerra, os juízes lançaram-se numa longa divagação sobre a tipologia dos conflitos, nacionais e internacionais, e analisaram as provas do caso, confrontando-as com este enquadramento teórico. A conclusão era que o conflito na Argentina era de âmbito puramente nacional. Os subversivos não tinham sido reconhecidos internacionalmente, não tinham dominado parte alguma do território e não tinham recebido assistência de forças externas. Por todas estas razões, as juntas não podiam alegar que o estado de guerra justificava

${ }_{10}$ Art. 34(6) e 34(7) do Código Penal, citado em Argentina (1987: 351-352). 
os seus meios repressivos (Argentina, 1987: 355); o sistema jurídico argentino previa vários mecanismos legais para lidar com os subversivos, quer em circunstâncias normais, quer extraordinárias. Além disso, a justiça internacional também proporcionava orientações suficientes para lidar com a situação. Apesar disso, as juntas haviam optado por agir fora da lei, negando, assim, os próprios valores que, supostamente, se tinham proposto defender (Argentina, 1987: 357-359).

Deste modo, as quatro razões justificativas alegadas pelos militares foram rejeitadas com base em explicações pormenorizadas, para, simultaneamente, assegurar a credibilidade e fazer passar a mensagem dos limites que a Constituição impunha à acção oficial. $O$ vasto espaço e atenção dados a estes quatro ângulos da defesa reflectiram uma preocupação com apresentar todos os pontos de vista, encorajando, assim, os vários públicos do tribunal a avaliar e tomar as suas próprias decisões sobre o caso. Provocava-se o raciocínio dos arguidos, de modo a levá-los a reflectir sobre as próprias justificações dos seus actos. Ao condenar a impunidade, reconhecia-se os motivos de queixa dos vitimadores, das vítimas e respectivas famílias, e da sociedade em geral.

A preocupação com as emoções públicas também levou o tribunal a uma vigorosa condenação do regime pela sua conduta atávica e por violar os valores orientadores da nação argentina:

Estas infracções penais violaram direitos legais de importância vital. Foram também actos cometidos contra a sociedade, na medida em que atacaram aspectos fundamentais da ordem jurídica que governa a sociedade como um todo [...] Os presentes actos processuais já determinaram que as tácticas empregues contra o terrorismo não estavam em conformidade com a lei em vigor, com a tradição argentina ou com os hábitos de nações civilizadas. Também ficou claro que o Estado tinha vários meios alternativos ao seu dispor, que eram totalmente adequados [...]. Dado que os meios usados foram atrozes e desumanos e tendo em conta que a sociedade ficou - e ainda está - chocada com tais actos, estes actos ilegais escapam aos padrões comportamentais e culturais desta Nação. [...] O interesse da Nação não é, nem nunca foi, a regressão para um estado primitivo de natureza. (Argentina, 1987: 352-353)

Os juízes prosseguiram, então, com uma abordagem da teoria de culpabilidade adoptada pela acusação. De modo cuidadoso e atento, explicaram o porquê de os arguidos terem sido considerados autores morais, e não materiais, dos crimes. Foi apresentado um conjunto significativo de argumentos a favor da "teoria de controlo" da culpabilidade, com o propósito de legitimar os procedimentos do tribunal e dizer "nunca mais" à 
opressão estatal. Desta forma, as reivindicações quer das vítimas, quer da sociedade, foram satisfeitas.

A acusação serviu-se de disposições do Código Penal e do Código Militar para acusar os arguidos de serem "autores indirectos" dos crimes cometidos pelos seus subordinados. Ao darem ordens e estarem em posição de determinar as consequências dessas mesmas ordens, os arguidos eram indirectamente culpados dos raptos e homicídios cometidos pelos seus subordinados, assim como de quaisquer outros crimes - roubos, abortos, violações - que pudessem ter sido cometidos (como efectivamente foram) no cumprimento dessas ordens. A defesa contestou esta abordagem, alegando que a "teoria de controlo" tinha vindo a ser rejeitada por vários autores, devido à dificuldade em determinar a responsabilidade criminal de todos os que ocupavam uma posição intermédia entre os autores indirectos e directos de crimes. ${ }^{11}$ É precisamente por esta razão que o código penal argentino não adoptou esta teoria da culpabilidade, tendo preferido, pelo contrário, a teoria "objectiva formal", segundo a qual apenas o autor directo ou principal do crime pode ser considerado criminalmente responsável.

Em resposta à defesa, o tribunal remontou ao autor da teoria, Hans Wetzel, e explicou como a doutrina foi incorporada nos padrões jurídicos da Argentina. De acordo com Wetzel, "o autor do crime é o indivíduo que, através de uma manipulação consciente do fim desejado e dos acontecimentos que conduzem a este fim, está ao comando da consumação do crime. Ele é a pessoa que controla o rumo dos acontecimentos, ou seja, não a vontade de realizar o acto, mas sim a vontade de controlar a realização do acto" (Argentina, 1987: 361). Embora, no passado, muitos juristas argentinos tenham adoptado a teoria "objectiva formal" de culpabilidade, mais recentemente, os estudiosos substituíram-na pela "teoria de controlo", argumentou o tribunal, após um percurso exaustivo pela bibliografia disponível. Os juízes salientaram ainda que esta teoria estava longe de ser uma invenção do sistema jurídico argentino e que tinha sido usada por muitos outros sistemas jurídicos (art. 514 do CMJ, in Argentina, 1987: 362). No entanto, num espírito de imparcialidade e de respeito pelo público, mas também para estimular a capacidade de discernimento e de tomada de decisão dos destinatários, o tribunal apresentou também um conjunto de objecções à "teoria de controlo". Ao incluírem argumentos tanto a favor como contra a tese de culpabilidade preferida pelo tribunal, os juízes

${ }^{11}$ A exegese jurídica é uma importante fonte para os sistemas do direito civil, daí a atenção prestada à investigação académica. 
esperavam demonstrar uma imparcialidade exemplar e incentivar públicos mais alargados a mostrar moderação e respeito pelos seus oponentes. Ao não suprimir os contra-argumentos, o tribunal mostrou como as democracias deveriam lidar com os repressores. Foi pormenorizadamente explicada a razão pela qual a "teoria de comando" era a mais apropriada nas circunstâncias em análise, perante um contexto repleto de provas incriminatórias esmagadoras. A importância dos argumentos invocados a favor da "teoria de controlo" não pode ser sobrestimada, na medida em que tanto a culpabilidade das chefias militares, como também a dos seus subordinados, dependiam das conclusões a que se chegasse neste julgamento.

A "teoria de controlo" reflectia-se, de forma evidente, nas disposições do Código Penal Militar, cujo artigo 514 estipulava que "quando um crime é cometido através do cumprimento de uma ordem, o oficial superior que emitiu a ordem deverá ser o único responsável. O oficial subordinado deverá ser considerado cúmplice apenas quando tiver excedido a observância dessa mesma ordem" (art. 514 do CMJ, in Argentina, 1987:361). Para apoiar a tese de que a lei militar reflectia a "teoria de comando", os juízes citaram ainda outras disposições legais que definiam os princípios da disciplina militar (art. 7 da Lei no 19101, RV 110/10; art. $^{\circ}$ 667, 674 e 675 do CMJ). O art. 11 da Lei 23049, que explicita o art. 514 do Código Penal Militar, estipulava que o subordinado seria passível de responsabilização se "ele tiver exercido poderes de tomada de decisão, tiver sabido que as ordens eram ilegais ou que a ordem exigia a consumação de actos atrozes ou execráveis" (Argentina, 1987: 363). O que significava, segundo o tribunal, que nem todos os subordinados que cumpriram ordens dos arguidos teriam a possibilidade de invocar alegarem a "obediência devida" em sua defesa. Com esta forma de interpretação da lei, o tribunal abriu caminho para outras acções judiciais contra militares de baixa patente.

Os juízes não se limitaram a mostrar que a lei militar incorporava a "teoria de controlo" de culpabilidade. Remontando a 1886, eles explicaram como a doutrina havia sido transmitida de uma versão do código penal para a versão seguinte, e assim consecutivamente, até se chegar à versão actual. Esta genealogia histórica das disposições legais relativas a autores indirectos de crimes tinha como objectivo legitimar os procedimentos do tribunal e demonstrar que o julgamento não estava a transformar ninguém em bodes expiatório. Quer em termos militares, quer em termos civis, as acusações feitas contra a junta eram legítimas.

Após ter delineado o sentido em que a "doutrina de controlo" fazia parte da tradição jurídica da Argentina, o tribunal determinou que as provas apontavam claramente para o facto de os arguidos se terem tornado 
autores morais de atrocidades quando decidiram lutar contra as guerrilhas de esquerda "à margem da lei e com recurso a métodos atrozes":

Os actos ilícitos foram cometidos através de uma cadeia de comando normal, cujo efeito era o de se sobrepor à legislação aplicável que conflituasse com as ordens emitidas. [...] As garantias de impunidade dadas aos autores directos ou aos autores reais dos crimes eram também parte do plano aprovado pelos réus. [...] Os réus tinham controlo sobre esses actos, visto que o aparato de pessoas e bens que possibilitou a consumação dos crimes se encontrava sob o seu comando. Os acontecimentos em causa não são o resultado de uma decisão errática, individual e isolada daqueles que os puseram em prática; fizeram parte de uma estratégia geral arquitectada pelos comandantes-em-chefe das forças armadas, com o intuito de combater a subversão. [...] Nestas circunstâncias, nem é assim tão importante saber quem consumou, de facto, os crimes. O controlo daqueles que chefiavam o sistema era absoluto. (Argentina, 1987: 363-364)

O sistema estabelecido pelos comandantes militares era constituído por homens intercambiáveis. O controlo dos comandantes era tal que, se um dos subordinados se recusasse a cumprir as ordens recebidas, seria imediatamente substituído por um outro. Contudo, os réus tiveram sempre o poder de impedir a consumação de crimes; e, apesar disso, continuaram a emitir ordens e a fornecer aos seus subordinados todo o equipamento necessário para continuar a "guerra suja" contra a subversão.

Tendo em consideração as provas testemunhais e documentais, a derrota destas várias estratégias de defesa e a demonstração da culpabilidade moral, o tribunal sentenciou os Generais Videla e Massera a prisão perpétua, o Brigadeiro Agosti a quatro anos e seis meses, o General Viola a dezassete anos, e Lambruschini a oito anos de prisão, e absolveu o General Galtieri, o Brigadeiro Graffigna e o Brigadeiro Lami Dozo (Argentina, 1987: 369-372). A sentença não foi bem recebida pelas famílias das vítimas. Foram organizados protestos de rua e feitos apelos para a aplicação de penas mais pesadas. As famílias de alguns dos desaparecidos dirigiram ao tribunal petições a exigir prisão perpétua para todos os arguidos. Estas petições estavam previstas na Lei 23049 , que estipulava que as vítimas e as suas famílias tinham o direito de iniciar acções judiciais e de interpor recursos. A acusação recorreu da sentença e requereu que todos os membros das juntas recebessem a mesma sentença. Também a defesa interpôs recurso, com a fundamentação de que as sentenças eram arbitrárias e a culpabilidade dos arguidos não tinha sido determinada (Amnesty International, 1987). O Supremo Tribunal apreciou o caso e reiterou as sentenças, com 
algumas reduções de pouca monta. Além disso, o tribunal reclassificou os perpetradores como "participantes directos", e não "autores morais", nos referente aos crimes mandados executar fora da esfera militar. O Supremo Tribunal declarou que os crimes cometidos contra civis em tempo de paz não se encontravam abrangidos pelo art. 514 do Código Militar, mas sim pelo código penal civil. A culpabilidade dos oficiais foi alterada de "autores indirectos" para "participantes que asseguraram a assistência necessária para a consumação dos crimes". ${ }^{12}$ Deste modo, a jurisdição dos tribunais civis sobre os oficiais das forças armadas recebeu uma justificação alternativa. O Supremo Tribunal rejeitou os recursos das famílias dos desaparecidos e da defesa, reafirmando a constitucionalidade e a correcção dos actos processuais. Apoiou a decisão dos juízes federais de um modo que demonstrou os limites do que pode ser feito em nome da indignação e do ressentimento públicos legítimos, no quadro de uma democracia constitucional. "Igual preocupação com todos" significava que a lei não podia ser contornada de forma a subordinar os direitos dos arguidos ao desejo de satisfação das vítimas. Se, por um lado, os arguidos precisavam de compreender que o que tinham feito era ilegal, tanto do ponto de vista do direito civil como do militar, as vítimas necessitavam de ser esclarecidas acerca das restrições que um compromisso para com a democracia impõe à manifestação pública de emoções morais.

Apesar de os processos contra os restantes oficiais terem sido travados com a aprovação das Leis de Ponto Final e de Obediência Devida, em 1986 e 1987, respectivamente, e apesar de os oficiais condenados no primeiro julgamento terem sido posteriormente perdoados pelo presidente Menem, estas acções judiciais mostraram ser possível a confrontação com um passado de violência e secretismo. A instabilidade contextual desfez, ao início, os pequenos passos dados contra a impunidade nos primeiros julgamentos dos militares; não obstante, as vítimas e as suas famílias continuaram com a mobilização social e jurídica até terem conseguido quebrar o muro de silêncio no início do século XXI. O juízo apurado no julgamento de 1985 poderá ter contribuído para esta mobilização, já que mostrou que uma democracia constitucional presta atenção tanto às vítimas como aos vitimadores. Os juízes tiveram em consideração os sobreviventes e reconheceram os seus traumas e sofrimento. Simultaneamente, explicaram que a descontinuidade com um passado de arbitrariedade exige que sejam ouvidos os gritos pela justiça, mas dentro dos limites do respeito por todas as partes e salvaguardando

12 Ver Supreme Court of Argentina (1986: 500-504). A opinião dissidente concordou com o veredicto inicial. 
as garantias processuais daqueles cuja culpabilidade não oferecia a mínima dúvida. A atenção séria aos argumentos da defesa foi um sinal do respeito que as democracias devem ter para com todos os seus membros. Só ouvindo o outro lado e confrontando-se construtivamente com os seus argumentos é que o regime podia mover-se na direcção certa. O longo caminho percorrido pelo tribunal até chegar à conclusão e a atenção cuidada prestada, sem excepção, a todos os argumentos apresentados pelos advogados de defesa mostram a determinação de inculcar valores democráticos, tanto relativamente aos réus, como às suas vítimas. Restabelecer o estado constitucional de direito exigiu um conjunto abrangente, exemplar e transparente de argumentos dirigidos ao público presente no julgamento e à sociedade em geral. A reflexão do tribunal teve por conclusão que a descontinuidade com as práticas criminosas do passado exigia um importante esforço por parte de uma instituição judicial anteriormente forçada à inacção.

Este artigo contesta, portanto, uma visão deste primeiro julgamento e das suas consequências imediatas como um caso em que a justiça tenha sido sacrificada em prol da estabilidade democrática. Pelo contrário, foi feita justiça de forma exemplar e, mesmo que os resultados obtidos tenham sido suspensos por algum tempo, eles podem ter continuado a inspirar e a encorajar a reflexão histórica no seio de uma população ultrajada. Simultaneamente, a possibilidade de reparação que a sentença representou deu início a uma discussão pública e continuou a mobilizar as vítimas e as suas famílias na luta pela memória e pela conquista de mais direitos.

\section{Roménia}

Nós somos o Povo, abaixo o comunismo! Morte ao assassino! Slogans anticomunistas, Bucareste, Dezembro de 1989

Entre 1965 e 1989, a Roménia permaneceu sob o domínio de um dos mais opressivos regimes comunistas de toda a Europa de Leste: o "sultanismo" (Linz e Stepan, 1998) ou "neo-estalinismo pessoal" (Tismăneanu, 1991) de Nicolae Ceaușescu. O controlo do partido único sobre a sociedade era um dos mais fortes da Europa de Leste. A polícia secreta, a tristemente famosa "Securitate", era usada para aniquilar qualquer dissidência ou resistência aos planos megalómanos do ditador que ambicionavam a colectivização, urbanização e controlo total da economia (Jowitt, 1971; Shafir, 1985). O projecto de Ceaușescu de pagar a totalidade da dívida externa da Roménia, de modo a alcançar a autonomia económica nacional, concretizou-se no Verão de 1989, ao preço de um racionamento humilhante de todos os bens de consumo, alimentos, abastecimentos públicos e gasolina imposto à população 
(Judt, 2005: 622-626). Uma política demográfica com motivações nacionalistas tornou o aborto ilegal nos anos sessenta e conduziu a uma elevada taxa de mortalidade de mulheres que recorriam a abortos ilegais em condições de risco. ${ }^{13} \mathrm{O}$ extermínio de cerca de 500000 a 2000000 resistentes políticos, a destruição do património cultural e o extraordinário culto da personalidade ${ }^{14}$ foram dimensões de um regime que recusava reformar-se, mesmo após o colapso do bloco comunista que o rodeava.

Aos primeiros sinais de descontentamento público em Dezembro de 1989, Ceaușescu ordenou às forças armadas e à Securitate que suprimissem as manifestações de rua organizadas pelas massas enfurecidas e desesperadas que exigiam a morte do tirano e o fim do regime comunista. Na Roménia, não houve a opção de uma negociação pacífica em torno de uma mesa redonda. Entre cem e mil pessoas foram mortas e muitas mais ficaram feridas. Ao mesmo tempo que as forças da Securitate continuavam, aparentemente, a lutar pelo "tirano" e a disparar contra a população e o exército, as altas chefias do exército aliaram-se discretamente a uma organização recentemente formada que depressa tomaria o poder, aproveitando o vácuo deixado pela fuga do ditador a 22 de Dezembro. A "Frente de Salvação Nacional", como era chamada, era formada por antigos apparatchiks comunistas de topo que tinham tido conflitos com Ceaușescu e, por consequência, sido marginalizados durante o último período do regime. Esses antigos dirigentes aproveitaram-se do movimento popular para se legitimarem como líderes da revolução e assumirem o controlo do país (Tismăneanu, 2008; Judt, 2005). Apanhados desprevenidos no turbilhão de acontecimentos, os verdadeiros dissidentes, na maioria intelectuais e figuras da cena cultural romena, não tiveram qualquer possibilidade nem capacidade organizativa para se porem a par da Frente.

A luta nas ruas continuou até 27 de Dezembro e destruiu vários edifícios de referência do centro da capital e da cidade de Timișoara. Como viria a verificar-se mais tarde, muitas das mortes tinham resultado de tiroteios de ambos os lados, num clima generalizado de medo, boatos e confusão. Algures entre 22 e 25 de Dezembro de 1989, Ceaușescu e a esposa - o segundo funcionário mais poderoso do regime - foram apanhados, presos, submetidos a julgamento sumário por um tribunal militar e executados em circunstâncias dúbias. Os registos audiovisuais do julgamento e da execução foram difundidos na televisão nacional no dia 25 de Dezembro. A lógica justificativa para exibir a gravação era a de que, após assistir à morte do seu

\footnotetext{
${ }_{13}$ Para um estudo das políticas demográficas de Ceaușescu, ver Kilgman (1998).

${ }_{14}$ Para um relato sucinto dos factores que influenciaram a queda de Ceaușescu, ver Tismăneanu (1993).
} 
chefe, a polícia secreta deixaria de disparar conta os manifestantes. Seguiu-se a desaprovação internacional e a condenação deste julgamento encenado. $\mathrm{O}$ assunto permaneceu rodeado de secretismo e, de início, muito poucos criticaram a execução, numa sociedade esfomeada, frustrada e traumatizada pelos anos passados sob a governação de Ceaușescu. O ódio acumulado contra o ditador e a sua família, enquanto personificações da opressão exercida pelo Estado, levou a que cidadãos comuns viessem para as ruas comemorar a morte de Ceaușescu. Porém, a forma como a Roménia lidou com o seu passado no período imediato que se seguiu à mudança política viria a deixar uma marca claramente negativa na cultura política da democracia que acabaria por emergir das cinzas da experiência estalinista. Embora possa haver quem argumente que foi realmente feita justiça, um compromisso com a democracia, enquanto regime institucional e normativo, exige que nenhum cidadão possa ser instrumentalizado com vista à satisfação de um desejo de vingança. O respeito por todas as partes e a consideração pelos direitos de todos são incompatíveis com violações das garantias processuais, mesmo no caso dos mais atrozes criminosos.

Esta secção irá analisar o julgamento e tentará demonstrar como este não serviu a causa da democracia. O que teve início como uma revolta popular genuína rapidamente se transformou numa quase-revolução que conduziu ao poder antigos líderes comunistas (Tismăneanu, 1991: 90-91). Ao atirar todas as culpas para Ceaușescu, estes esperavam conseguir evitar uma análise lúcida e abrangente do sistema opressivo a que eles próprios tinham pertencido. Um véu de secretismo continuou a proteger uma burocracia permeada de não-democratas. Existem boas razões para acreditar que, por não terem sido tratados de modo satisfatório, a indignação e o ressentimento públicos foram-se reproduzindo ao longo do tempo e contribuíram para o desenvolvimento de patologias na sociedade civil: desilusão, apatia e falta de confiança nas instituições políticas. ${ }^{15}$

O julgamento de Nicolae e Elena Ceaușescu por um tribunal militar extraordinário instalado numa base do exército foi organizado pelo ministro da Defesa do próprio ditador, o general Victor Atanasie Stănculescu. Em colaboração com a Frente de Salvação Nacional - o organismo constituído por antigos comunistas que, a certa altura, tinham sido afastados por Ceaușescu ${ }^{16}-$, o general organizou o tribunal e ordenou aos magistrados militares que julgassem o ditador e a mulher. O julgamento durou menos de uma hora e violou praticamente todas as normas processuais. As transcrições

15 Sobre o estado socioemocional pós-decembrista da Roménia, ver Tismăneanu (1993).

16 Para informações sobre as biografias e as razões da queda em desgraça, ver Raportful Final (2006). 
revelam que todos, tanto a acusação, como o juiz e os advogados, acusaram o casal que, por repetidas vezes, se recusou a reconhecer a legitimidade do tribunal e dos seus procedimentos (Transcript, 1989).

Após uma introdução bastante incoerente em que denunciava a inanição a que o povo romeno tinha sido sujeito enquanto uma minoria privilegiada vivia no maior dos luxos, o juiz autorizou o promotor público a enumerar as acusações. As quatro acusações baseavam-se no código penal romeno então em vigor e consistiam no seguinte: genocídio cometido durante a revolta popular, subversão do poder do Estado e ataque armado às instituições do Estado, organização de manobras de diversão com vista à destruição de instalações industriais, e comprometimento da economia nacional (Transcript, 1989). Embora o uso pelo tribunal da lei existente confirmasse a continuidade jurídica com o regime anterior, o casal foi acusado de, vergonhosa e impunemente, usar as estruturas do Estado em seu próprio proveito.

Ceaușescu negou-se a reconhecer a legitimidade das acusações. Furioso, o juiz lançou-se numa tirada inflamada sobre a penúria imposta ao povo romeno, sobre as 64000 pessoas $^{17}$ que, alegadamente, tinham morrido em consequência da repressão das manifestações de ruas em Bucareste e Timișoara, e o exílio da intelligentsia. Os advogados de defesa fizeram então questão de explicar a legitimidade e legalidade dos procedimentos. $\mathrm{Na}$ qualidade de presidente do país, Ceauşescu só teria de responder judicialmente perante a grande assembleia legislativa (MAN); contudo, uma vez que tinha perdido o seu cargo em resultado da "vontade soberana do povo", ele teria de ser julgado como um qualquer cidadão comum. Em resposta à exposição dos advogados, o casal insistiu que ambos tinham sido vítimas de uma conspiração e que só prestariam contas dos seus actos perante a MAN. Ainda mais furioso, o juiz passou a acusar o casal da destruição do campesinato romeno através de planos forçados de urbanização ${ }^{18} \mathrm{e}$, uma vez mais, voltou a comparar a pobreza dos cidadãos comuns por oposição ao estilo de vida luxuoso do clã. A acusação levantou, então, questões acerca das contas bancárias secretas na Suíça, nas quais o dinheiro obtido através da exploração do país teria sido alegadamente depositado. Nesse momento, Elena Ceauşescu exigiu que fossem apresentadas provas para comprovar

\footnotetext{
${ }_{17}$ Este número era um exagero grosseiro, o número de pessoas mortas, como já referido, oscilava entre 100 e 1000. É possível que o juiz tenha sido, ele próprio, vítima da manipulação do general Stănculescu. Dominado pela depressão e pelo medo das consequências das suas acções durante o julgamento, o juiz viria a suicidar-se no início dos anos 90 . Ver a entrevista com o promotor de justiça do julgamento in "Cadavrele ceaușeștilor, filmate de Ţopescu" (2005).

${ }_{18}$ Cerca de 13000 aldeias, predominantemente de regiões habitadas por minorias étnicas, foram transformadas, de um dia para o outro, em "agro-cidades". Isto estava em sintonia com a ideia de "modernização como urbanização" defendida pelo ditador.
} 
tais acusações. De forma retórica e sarcástica, o juiz prometeu que as provas seriam disponibilizadas, ao mesmo tempo que o promotor de justiça fazia comentários pouco profissionais acerca da saúde mental dos arguidos.

O tom sarcástico e enfurecido manteve-se quando foi abordado o tema da carreira científica forjada de Elena Ceaușescu. Desconhecendo que tinha sido o próprio homem por detrás do julgamento, o general Stănculescu, a ordenar pessoalmente a carnificina em Timișoara, o juiz exigiu obsessivamente saber quem era responsável pelas lutas nas ruas. Outros dos temas recorrentes foi o da inanição generalizada, a frustração mais directa que os Romenos tiveram de suportar nos últimos anos da ditadura. A inimaginável impunidade psicológica que a Roménia tinha enfrentado durante mais de quatro décadas estava por trás da revolta popular. Os magistrados presentes no julgamento exprimiram, com veemência, a sua desaprovação e aversão moral, relativamente aos arguidos e ao seu aparelho repressivo. A julgar pelas declarações dos colegas, dá a impressão de que, apesar da sua falta de profissionalismo, as manifestações emocionais do juiz em relação às atrocidades cometidas pelo casal eram sinceras ("Cadavrele Ceauşeştilor, filmate de Tुopescu”, 2005).

Cansado de uma conversa que não estava a conduzir a lugar nenhum, o promotor de justiça pediu a pena de morte e a expropriação total dos bens do casal. Em resposta, os advogados de defesa reiteraram os fundamentos da legalidade do julgamento, declarando que estavam a fazer um favor ao casal, ao defender um tirano que, em plena posse das suas capacidades mentais, havia cometido atrocidades contra o seu próprio povo, e declararam que consideravam o réu culpado de todas as acusações. Seguiu-se um longo rol de acusações. Os advogados expressaram a sua indignação com a falta de medicamentos nos hospitais, a vigilância da Securitate, o golpe que levou os comunistas ao poder em 1947 e as mortes dos manifestantes nos dias anteriores. Num gesto simbólico, porém, apelaram ao juiz para não deixar que o julgamento degenerasse numa vendetta.

Após um curto período de deliberação, o tribunal pronunciou a sentença: pena de morte e expropriação total. Os advogados tentaram dialogar com os dois réus com o intuito de recorrer da decisão, mas, uma vez mais, Ceauşescu recusou-se a reconhecer a autoridade do tribunal. Em consequência, os advogados declararam que o não reconhecimento do tribunal fazia com que o casal Ceaușescu perdesse o direito ao recurso. Os Ceaușescu foram executados de imediato e, na noite de Natal de 1989, os Romenos assistiram à morte do ditador e da mulher pela televisão. Ao atribuir todas as culpas ao casal, os novos dirigentes do país tinham assegurado, de forma estratégica, a impunidade do aparelho comunista e dos seus agentes. 
Desde 1989, sempre que chega a época de Natal, os canais de televisão repetem a transmissão da gravação, organizam debates, mostram documentários e entrevistam participantes, tudo num esforço de apurar o que realmente aconteceu. Quem participou nos tiroteios nas ruas? Quem esteve por detrás do julgamento? À medida que os anos passaram e a verdade não veio ao de cima, os cidadãos especularam, formularam teorias da conspiração, mergulharam no cinismo e desenvolveram uma total falta de confiança na capacidade de as instituições do Estado se confrontarem com o passado (Gross et al., 2005). A impunidade associada à repressão comunista foi substituída pela impunidade de um regime pós-comunista duvidosamente democrático, caracterizado pela suspeição e a incerteza. Em resultado disso, a sociedade civil, apática, amargurada e desconfiada falhou no exercício da sua função essencial de exigir contas a um governo endemicamente corrupto.

Nada no julgamento poderia ser recomendado como um acto exemplar de justiça democrática. Ele teve lugar num tribunal militar ad hoc, mas a lei invocada durante o processo foi a do código penal civil. Não foram apresentadas quaisquer provas, não houve depoimentos por testemunhas e todos os magistrados, incluindo a defesa e o juiz, estiveram do lado da acusação. A condução da sessão ficou marcada por longos e virulentos discursos condenatórios, carregados de retórica e, por vezes, incoerentes, devido à atmosfera de forte carga emocional. A aversão moral de todos para com os réus, desde os juízes aos soldados que executaram o casal, é claramente visível na transcrição e na gravação de vídeo. Embora legítimos, dadas as atrocidades cometidas a mando dos réus, a indignação e o ressentimento desmedido da equipa jurídica não foram expressos, de forma apropriada, num tribunal de direito cuja finalidade seria pôr fim a um regime de arbitrariedade e caminhar rumo à democracia e liberdade. $\mathrm{O}$ julgamento representou, em todos os aspectos, um abuso judicial e não fez passar quaisquer lições didácticas para uma população igualmente enraivecida. Ao participarem irreflectidamente no jogo planeado pelo general Stănculescu e pela Frente, os magistrados ajudaram a desviar a Roménia do rumo democrático que ela tinha vindo a seguir nos primeiros tempos da revolta popular. ${ }^{19} \mathrm{O}$ comandante supremo do país tinha sido eliminado e as múltiplas vítimas do seu regime continuavam sem voz, enquanto o sistema e os seus sucessores permaneciam

\footnotetext{
${ }^{19}$ Em relação a este ponto, pode argumentar-se que um tribunal internacional teria sido uma melhor solução para a Roménia. Pondo de parte o facto de, naquela altura, os tribunais internacionais não serem verdadeiramente uma opção, gostaria de defender que esta não era necessariamente a única saída. Uma maior reflexão por parte dos magistrados e um maior compromisso com o processualismo poderiam ter frustrado as manobras políticas dos organizadores do golpe.
} 
todos praticamente no mesmo lugar, tendo continuado a governar ${ }^{20}$ até 1996 , altura em que a oposição liberal democrática finalmente venceu as eleições presidenciais e parlamentares.

Somente em 1997, após a primeira transição de poder pacífica entre as velhas forças (FSN) e as novas forças (a Convenção Democrática), o Ministério Público começou a investigar o papel desempenhado pelo general Stănculescu nos acontecimentos de 1989. Em 2000, um tribunal considerou-o culpado de homicídio qualificado e condenou-o a quinze anos de prisão. Apesar disso, com a epidemia do desastre económico a contaminar o mandato liberal-democrático, os Romenos votaram a favor do regresso ao poder, entre 2000 e 2004, do partido que sucedeu à Frente. Consequentemente, foi introduzido um procedimento especial de recurso para prolongar as acções judiciais contra o general e assegurar a impunidade dos seus actos. Em 2007, um ano depois das eleições que trouxeram os liberais-democratas de volta ao poder, foi reconfirmada a sentença inicial. Actualmente, Stănculescu está a lutar pela suspensão da sua pena, alegando razões médicas. ${ }^{21}$

O domínio do partido sucessor da Frente, no panorama político romeno posterior a 1989, adiou a possibilidade de uma confrontação lúcida com o passado até 2007, altura em que uma comissão de especialistas nomeada pelo presidente elaborou um relatório de 666 páginas sobre a repressão comunista e pós-comunista na Roménia. ${ }^{22} \mathrm{O}$ relatório contém informação documentada cientificamente e um conjunto de recomendações para um projecto holístico de justiça de transição, que inclua responsabilidade legal, educação cívica, aplicação de medidas de inibição a membros do aparelho repressivo e memoriais dedicados às vítimas. Contudo, o debate público em torno do documento ficou marcado por discursos racistas difamatórios contra o director da comissão. Os Romenos ainda têm de adoptar hábitos deliberativos e respeitar as regras emocionais de expressão. ${ }^{23}$ Foram necessários

\footnotetext{
${ }^{20}$ Seguiu-se, no Verão de 1990, uma violenta repressão dos dissidentes intelectuais e do movimento estudantil contra a continuação do regime comunista, quando o líder da Frente, então presidente do país, convocou mineiros de Valea Jiului para "pôr na ordem" os "hooligans" que contestavam o seu poder.

${ }^{21}$ Sobre a trajectória sinuosa dos julgamentos do general, ver Culcer (2008).

${ }^{22}$ Ver Raportful Final (2006).

23 Para um relato dos ataques injuriosos, organizados pela esquerda e por grupos de extrema-direita, que a comissão e o seu presidente tiveram de enfrentar, ver Tismăneanu, 2008. Em 1999, foi criada uma comissão para estudar os ficheiros da Securitate, numa tentativa de lançar luz sobre a actuação da tão odiada instituição; porém, a comissão encontrava-se gravemente incapacitada pelos seus próprios estatutos: os ficheiros permaneciam sob o controlo da instituição sucessora da Securitate e esta poderia negar à comissão o acesso aos ficheiros, alegando razões de "interesse do Estado" (Stan e Turcescu, 2005).
} 
dezanove anos e o fim do reinado do partido sucessor do comunismo, para que o país começasse a reconciliar-se com um prolongado passado de dor. Resta a esperança de que, dando, finalmente, o reconhecimento e respeito devidos às vítimas, a democracia romena consiga estar à altura dos seus princípios e abalar a apatia política e o ressentimento público que têm vindo a contaminar a esfera pública do país ao longo de quase duas décadas.

\section{Lições a tirar}

Procurei analisar as diferentes estratégias usadas por dois tribunais chamados a confrontar-se com um passado de opressão apadrinhada pelo Estado. Foi prestada especial atenção às circunstâncias políticas precárias nas quais estes tribunais foram forçados a agir. A ameaça de uma nova intervenção militar na Argentina e a penetrante incerteza induzida pela manipulação política durante os dias revolucionários de 1989 na Roménia tornaram a tarefa do poder judicial extremamente difícil em ambos os casos. Embora orientadas por um compromisso de pôr fim à impunidade e reafirmar um respeito igual por todos os cidadãos, as decisões dos tribunais que foram alvo deste estudo tiveram de se adaptar à situação e reconhecer os limites da lei ao longo do processo.

O primeiro julgamento das juntas militares na Argentina demonstrou um interesse em transmitir preocupação, quer com o sofrimento das vítimas e das suas famílias, quer com o direito dos vitimadores a um julgamento justo. Embora alguns críticos realistas encarem a derrota dos esforços de Alfonsín como uma prova clara de que a justiça tem de ceder para dar lugar à democratização, o presente artigo veio defender as qualidades exemplares e inspiradoras deste primeiro julgamento no contexto da luta argentina pela memória. O longo e elaborado veredicto constituiu uma lição de justiça democrática com o potencial de provocar as capacidades morais de reflexão dos seus destinatários. Embora não possa ser dito que a Argentina alcançou uma justiça perfeita para as vítimas, o país, pelo menos, deu passos corajosos de aproximação, na prática, do princípio do respeito igual por todos. ${ }^{24}$

Pelo contrário, ao cederem ao seu próprio ódio em relação aos opressores e ao não conseguirem opor-se aos planos da nova elite para culpar o líder comunista pela impunidade estrutural que assolava a Roménia, os magistrados envolvidos no julgamento de Ceaușescu falharam em vários aspectos. Não foi dado o reconhecimento apropriado às inúmeras vítimas,

\footnotetext{
${ }^{24}$ Em certo sentido, devido à natureza e escala dos crimes com que se confrontam, todos os pro-
} cessos de justiça de transição estão condenados à imperfeição. 
o casal foi culpado de tudo o que tinha acontecido de errado no país desde 1947, e não foi transmitida nenhuma lição acerca daquilo que uma democracia exige aos seus cidadãos. Em vez de serem abordados construtivamente num diálogo imparcial sobre o porquê de a Roménia ter permanecido sob a repressão comunista desde 1947, a indignação e o ressentimento foram exclusivamente canalizados contra o ditador e a mulher, num acto absolutamente flagrante de construção de um bode expiatório. Embora não seja fácil dizer o que o tribunal poderia ter feito nas espinhosas condições da transição, é igualmente difícil ignorar o facto de ele ter contribuído, de forma irreflectida, para comprometer o primeiro impulso do país rumo à democracia. Neste sentido, o caso romeno serve de advertência em relação ao impacto negativo que um julgamento atamancado teve no desenvolvimento futuro de uma cultura emocional democrática.

Tendo em conta que este artigo abordou dois casos extremamente diferentes, pode perguntar-se se estas análises serão ou não úteis para lidar com casos que se encontrem numa posição intermédia, nomeadamente casos em que medidas de justiça democrática coexistam com uma "justiça" privada abusiva. A expectativa deste artigo foi, em primeiro lugar, a de chamar a atenção para um julgamento exemplar a que outros tribunais possam aspirar. A confrontação dialógica do tribunal argentino com os argumentos, quer da acusação, quer da defesa, exemplifica o que significa aplicar uma preocupação e um respeito igualitários de forma institucional, tentando assim educar as emoções públicas. A atenção dos juízes simultaneamente para com as vítimas e os réus mostra que todos precisam que lhes seja dada voz e que as emoções de todos têm de ser levadas a sério. Apenas assim poderá preservar-se um compromisso com a democracia e o constitucionalismo. Em segundo lugar, o caso romeno pretendia servir de sinal de alarme sobre o que pode acontecer se as emoções não forem filtradas e abordadas de forma institucional. Infelizmente, a Roménia não é o único caso em que sociedades sem tribunais funcionais e sem garantias processuais entraram num ciclo de violência motivado pelo ódio. As lições positivas e negativas a retirar destes contextos podem colocar os actores políticos numa melhor posição para compreender o tipo de desafios, mas também de oportunidades, que as manifestações públicas das emoções criam para os decisores em períodos de transição. Ainda que cada contexto possua traços específicos que não serão encontrados em nenhum outro lugar, a presença das emoções públicas molda transições de todo o género, sejam elas mais ou menos radicais.

Com a análise destes dois casos, espero ter ilustrado os modos como os tribunais escolheram lidar, de forma mais ou menos exemplar, com um passado 
de violência e repressão. Embora não possamos subestimar os obstáculos práticos, também não devemos desperdiçar as oportunidades didácticas associadas aos julgamentos nacionais. Ambos os julgamentos aqui apresentados tiveram lugar em condições de tensão emocional. As variáveis que definiram os contextos em causa desempenharam um papel importante na avaliação que os juízes fizeram das vias alternativas de julgamento. Se, por um lado, os juízes argentinos fizeram o melhor possível naquela situação, ajudando temporariamente a acabar com o reinado de impunidade e filtrando a aversão moral pública através do princípio do respeito igualitário e da preocupação com todos, o tribunal romeno, por sua vez, não esteve à altura da situação. Ao olhar novamente para estas experiências, espero ter fornecido elementos tanto de inspiração como de advertência para sociedades que estejam a considerar uma confrontação com o passado orientada por linhas democráticas.

Tradução de

Inês Martins Ferreira

\section{Referências bibliográficas}

Arendt, Hannah (1963), Eichmann in Jerusalem: A Report on the Banality of Evil. London: Faber \& Faber.

Bass, Gary Jonathan (2000), Stay the Hand of Vengeance. Princeton NJ: Princeton University Press.

Bassiouni, M. Cherif (org.) (2002), Post-conflict Justice. Ardsley NY: Transnational Publishers. Bhargava, Rajeev, "Restoring Decency to Barbaric Societies”, in Robert I.; Rotberg, Dennis Thompson (orgs.) (2000), Truth v. Justice: The Morality of Truth Commissions. Princeton NJ: Princeton University Press, 45-67.

Bilsky, Leora (2007), Transformative Justice: Israeli Identity on Trial. Ann Arbor, MI: University of Michigan Press.

Di Paolantonio, Mario (2004), "Tracking the Transitional Demand for Legal Recall: The Foreclosing and Promise of Law in Argentina", Social Legal Studies, 13, 351-375.

Douglas, Lawrence (2001), The Memory of Judgment: Making Law and History in the Trials of the Holocaust. New Heaven CT: Yale University Press.

Gross, Peter et al. (2005), "The End of Post-Communism in Romania," Journal of Democracy, 16(2), 146-163.

Hayner, Priscilla (2001), Unspeakable Trutbs: Confronting State Terror and Atrocity. New York NY: Routledge.

Henham, Ralph (2007), "Some Reflections on the Legitimacy of International Trial Justice," International Journal of the Sociology of Law, 35, 75-95. 
Jacobson, Douglas (2006-2007), “A Break with the Past or Justice in Pieces: Divergent Paths on the Question of Amnesty in Argentina and Colombia," Georgia Journal of International and Comparative Law, 35, 135-204.

Jowitt, Kenneth (1971), Revolutionary Breakthroughs a nd National Development: The Case of Romania. Berkeley Ca: University of California Press.

Judt, Tony (2005), Post-war: A History of Europe Since 1945. Penguin.

Kilgman, Gail (1998), The Politics of Duplicity: Controlling Reproduction in Ceausescu's Romania. Berkeley CA: University of California Press.

Kritz, Neil (1995), “Argentina: Editor's Introduction”, in Neil Kritz (org.), Vol. 2, Transitional Justice. Vol. 1-3, Washington DC: US Institute of Peace Press.

Linz, Juan; Stepan, Alfred (1998), "The Effects of Totalitarianism-cum-Sultanism on Democratic Transition: Romania," in Problems of Democratic Transition, Problems of Democratic Transition and Consolidation: Southern Europe, South America and Post-Communist Europe. New York: New York University Press, 344-365.

Mégret, Frédérich (2005), "In Defence of Hybridity: Towards a Representational Theory of International Criminal Justice,” Cornell International Law Review, 38, 725-752.

Mignone, Emilio Fermin et al. (1985), "Dictatorship on Trial: Prosecution of Human Rights in Argentina," Yale Journal of International Law, 10, 118-150.

Nino, Carlos (1996), Radical Evil on Trial. New Haven CT: Yale University Press.

Osiel, Marc (1997), Mass Atrocity, Collective Memory and the Law. New Brunswick NJ: Transaction Publishers.

Penrose, Margaret (1999), "Impunity, Inertia and Invalidity: A Literature Review,” Boston University International Law Review, 17, 269-310.

Rabkin, Jeremy (2005), "Global Criminal Justice: An Idea Whose Time Has Passed,” Cornell International Law Review, 38, 753-778.

Stover, Eric; Weinstein, Harvey M. (orgs.) (2004), My Neighbor, My Enemy: Justice and Community in the Aftermath of Mass Atrocity. Cambridge: Cambridge University Press.

Shafir, Michael (1985), Romania: Politics, Economics and Society. Boulder CO: Lynne Riener.

Stan, Lavinia; Turcescu, Lucian (Novembro de 2005), "The Devil's Confessors: Priests, Spies, Communists, and Informers", East European Politics and Society, 19(4), 655-685.

Tismăneanu, Vladimir (1991), "The Revival of Politics in Romania," Proceedings of the Academy of Political Science, 38(1), 85-99.

Tismăneanu, Vladimir (Primavera de 1993), "The Quasi-Revolution and Its Discontents: Emerging Political Pluralism in Post-Ceaușescu Romania," East European Politics and Society, 7(2), 309-348.

Tismăneanu, Vladimir (2008), "Democracy and Memory: Romania Confronts its Communist Past," The ANNALS of the American Academy of Political and Social Science, 617, 166-180. 
Uitz, Renata (2005), Constitutions Courts and History. Historical Narratives in Constitutional Adjudication. Budapest: CEU Press.

Walker, Margaret Urban (2006), Moral Repair: Reconstructing Moral Relations after Wrongdoing. Cambridge: Cambridge UP.

\section{Relatórios e Legislação}

Americas Watch, Truth and Partial Justice in Argentina: An Update (Human Rights Watch, 1991).

Amnesty International, Argentina: The Military Junta and Human Rights Report of the Trial of the Former Junta Members (Amnesty International Publications, 1987), 10-13. Argentina: National Appeals Court (Criminal Division), "Judgment on Human Rights Violations by Former Military Leaders,” (Excertos), 9 de Dezembro de 1985, International Legal Materials, Vol. 26 (1987), 317-372.

Ley 22924 de 22 de Setembro de 1983. Acedido a 14/03/09, http://ejp.icj.org/IMG/ Ley_22924.pdf.

Ley 23049, Boletin Oficial de la Republica Argentina, 25365 (15 de Fevereiro de 1984). Acedido a 20/03/09, em http://ar.vlex.com/vid/ley-23049-25621000.

Raportul Final al Comisiei Presidentiale Consultative pentru Analiza Dictaturii Comuniste din Romania, Bucharest 2006. Acedido a 28/03/09, http://cpcadcr.presidency. ro/upload/RAPORT_FINAL_CPADCR.pdf.

Supreme Court of Argentina, Buenos Aires, Judgment of December 30, 1986, reproduzido in Kritz, Transitional Justice, 3, 500-504.

\section{Artigos de jornais}

"Cadavrele ceausestilor, filmate de Tुopescu" (3 de Novembro de 2005), Jurnalul National. Acedido a 20/03/09, http://www.hotnews.ro/stiri-arhiva-1202344-cadavrele-ceausestilor-filmate-topescu.htm.

Culcer, Rodica (22 de Outubro de 2008), "Stănculescu si Chiţac: un cuplu sinistru”, Revista 22. Acedido a 20/03/09, http://www.revista22.ro/stanculescu-si-chitac-un-cuplu-sinistru-4889.html.

"Transcript of the Closed Trial of Nicolae and Elena Ceaușescu" (29 de Dezembro de 1989), Washington Post. Acedido a 20/03/09, http://www.encyclopedia.com/doc/ 1P2-1230896.html.

Tremlett, Giles (20 de Abril de 2005), "Argentinean jailed for throwing prisoners from plane,” The Guardian, Acedido a 16/03/09, http://www.prisontalk.com/forums/ showthread.php?t=119916. 